\title{
TAX COMPETITION AND PROFIT SHIFTING: ON THE RELATIONSHIP BETWEEN PERSONAL AND CORPORATE TAX RATES
}

\author{
Clemens Fuest \\ ALFONS WEICHENRIEDER
}

CESIFO WORKING PAPER NO. 781

CATEGORY 1: PUBLIC FinANCE

OCTOBER 2002

PRESENTED AT CESIFO CONFERENCE 'CORPORATE AND CAPITAL

INCOME TAXATION IN THE EU’, MONS, DECEMBER 2001

\footnotetext{
An electronic version of the paper may be downloaded

- from the SSRN website: www.SSRN.com

- from the CESifo website: www.CESifo.de
} 


\title{
TAX COMPETITION AND PROFIT SHIFTING: ON THE RELATIONSHIP BETWEEN PERSONAL AND CORPORATE TAX RATES
}

\begin{abstract}
The residence-based taxation of interest income in the EU faces the difficulty that taxpayers may evade taxation by holding bank accounts in other countries. The EU therefore makes considerable efforts to achieve cooperation among EU member states in order to improve tax enforcement. The present paper argues that international cooperation in tax enforcement may not be sufficient to implement an effective taxation of interest income. The reason is that taxpayers may also avoid income taxes by holding financial assets in the corporate sector. If corporate tax competition reduces corporate income tax rates below personal income tax rates, taxpayers will increasingly shift income from the personal to the corporate sphere. We show that this type of income shifting is empirically important. According to our results, a one percentage point increase in the personal income tax rate increases the fraction of private savings held within corporations by approximately 2.6 percentage points.
\end{abstract}

JEL Classification: H20, H70, D9.

\author{
Clemens Fuest \\ University of Cologne \\ Meister Ekkehart Str. 11 \\ $50931 \mathrm{Köln}$ \\ Germany \\ clemens.fuest@uni-koeln.de
}

\author{
Alfons J. Weichenrieder \\ University of Vienna \\ Hohenstaufengasse 9 \\ A-1010 Vienna \\ Austria \\ weichenrieder@cesifo.de
}

We thank Thiess Buettner, Steven Clark, Marcel Gerard, Stephane Guimbert, Jim Hines, Vesa Kanniainen, Seppo Kari, Ruud de Mooij, Leif Mutén, Åsa Leander, Paolo Pantheghini, Ulf Pedersen, Guttorm Schjelderup, Christian Valenduc, and Varsha Venkatesh for helping us in collecting the panel data on tax rates for various countries. We are indebted to Jeremy S. Edwards for extremely helpful discussions and to Roger Gordon for valuable comments. We claim full responsibility for remaining deficiencies. 


\section{Taxing Capital Income}

All EU countries, at least conceptually, tax private capital income according to the residence principle. If perfectly enforced, the residence principle has several favorable features. For once, it ensures capital export neutrality even if tax rates on capital income differ across countries. That is, taxes do not distort an investor's decision of where to invest his or her savings. This can be shown to lead to a maximum of global pre-tax income. A second and closely related feature of the residence principle is that it separates national decisions on the size of tax rates on capital. Under the residence principle, a country that increases its tax rate on personal capital income does not have to fear that foreigners withdraw their savings, nor will national investors send their savings abroad, as such a move would not alter the tax rate faced by domestic or foreign investors. ${ }^{1}$

The Achilles heel of the residence principle however is enforceability. Without international cooperation, it is very hard to tell how much capital income domestic investors receive from foreign sources. Therefore, the European plans to limit bank secrecy laws and to foster international information exchange between authorities can be interpreted as an effort to improve the enforcement of the residence principle. In the light of the above virtues of this principle this can be seen as a measure to increase national governments' independence in taxation issues. ${ }^{2}$ Note that even the alternative measure of a withholding tax on cross border income (also discussed in the EU), while contradicting the idea of pure residence taxation, may lead to similar results. This is because it increases investors' incentives to claim a foreign tax credit (which usually is granted in tax systems that follow the residence principle) and thereby raises their willingness to report foreign income.

\footnotetext{
${ }^{1}$ A caveat applies if investors themselves face low costs to move abroad. At least with language and cultural barriers still in place this may not be of immediate concern.

${ }^{2}$ For decades, the UK has argued against coordination in Europe and in favor of tax competition hoping this will result in low taxes on capital. If co-ordination is restricted to the coordinated application and enforcement of the residence principle, however, nothing prevents a single country (the UK) from lowering its tax rate.
} 
While the application of the residence principle is conceivable for private households, it is not very realistic for incorporated firms. More or less all international double-taxation agreements grant an unlimited right to the host country of foreign corporations to subject these corporations to the national corporate income tax (as long as taxation is not discriminatory). As a result, this implements the source principle of taxation for corporations. While it is true that the home country of a corporation may additionally tax repatriated profits and use a tax credit system similar to those applied to private foreign income, there is a fundamental difference. In the case of a corporation foreign profits stay untaxed in the home (residence) country of the corporation until repatriation. This possible deferral of home country taxes makes source taxes much more important for corporations than for private, truly reporting households who lack the possibility of deferral.

A major question that appears in this context is whether enforcing the residence principle for private investment income is enough to safeguard the viability of capital taxation. It is well conceivable that, on the one hand, European and international co-operation in tax matters enforces the residence principle of taxation for households but, on the other hand, continued corporate tax competition significantly decreases the tax rate faced by corporations. In such a situation, how much of a difference in private and corporate tax rates on capital is realistic? Can an asymmetric approach towards private and corporate income be sustained? Or is a high tax on private capital income bound to fail if the corporate income tax, which performs an important withholding function for the income tax, ${ }^{3}$ is lowered in the process of tax competition.

The above questions motivate the present paper. In particular, we want to shed some light on the question of what effects a larger gap between personal and corporate income taxes would have on private behavior. We are hoping that the answer to these questions will improve our understanding of how rewarding the enforcement of the residence principle for

\footnotetext{
${ }^{3}$ See e.g. Mintz (1995).
} 
private savings would be, given that there is no effort (nor any success) to limit the downward trend in corporate tax rates.

The paper is organized as follows. Section 2 discusses the tax incentives for and against savings through a corporate firm instead of saving privately. Section 3 sets up a simple model that forms the basis of our empirical estimates. Against the background of the theoretical model, section 4 considers the optimal national tax policy that is confronted with the stylized facts in section 5. Section 6 presents our empirical results. Section 7 concludes.

\section{The Advantage of the Corporate Shelter}

When different types of income are subject to different tax rates, tax payers will have an incentive to declare one additional Euro of income in a low taxed basket if this saves them from having to declare one Euro of income in a high taxed basket. In the literature, this problem of income shifting has been discussed extensively with respect to multinational corporations. Internationally operating firms may use transfer prices or adjust their financial structure in order to shift income from high tax countries to low tax countries (see, e.g. Weichenrieder (1995) or Keen (1993)) and there is quite some evidence that they actually do so (Altshuler and Grubert (2000)).

There is a smaller but growing literature on income shifting within countries, between the personal and the corporate income tax bases. One problem of having a low corporate income tax rate but high personal income taxes arises as managers have an incentive to relabel labor income as capital income, effectively reducing their tax on salaries. This problem has been analyzed by Gordon and MacKie-Mason ${ }^{4}$ and has received extensive consideration in connection with Nordic dual income tax systems. ${ }^{5}$ Gordon and Slemrod (1998) provide an empirical study of income shifting between labor income and corporate profits for the U.S.

\footnotetext{
${ }^{4}$ Gordon and MacKie-Mason (1995) argue that for this reason it may be even in the interest of a small country to employ a positive corporate tax rate.

${ }^{5}$ See e.g. Cnossen (1999).
} 
They show that differences between the personal and the corporate tax rates have a significant impact on reported labor income and corporate rates of return.

The present paper highlights another effect of differences in personal and corporate tax rates: the increased incentives for private investors to use the corporate shelter to save their capital income from high personal taxes. Figure 1 illustrates this effect. Assume a fixed interest rate $r$ and personal and corporate tax rates at a rate $t$ and $\tau$, respectively. For $t>\tau$, any initially invested Euro will grow at a higher growth rate if invested within the corporation than when invested in the personal sphere: $r(1-\tau)>r(1-t)$. Growth path $a$ associated to the corporate investment is clearly steeper than growth path $c$ associated to the private investment and total assets $W$ accumulated will accordingly be higher.

Figure 1: Outgrowing the high-tax Investment

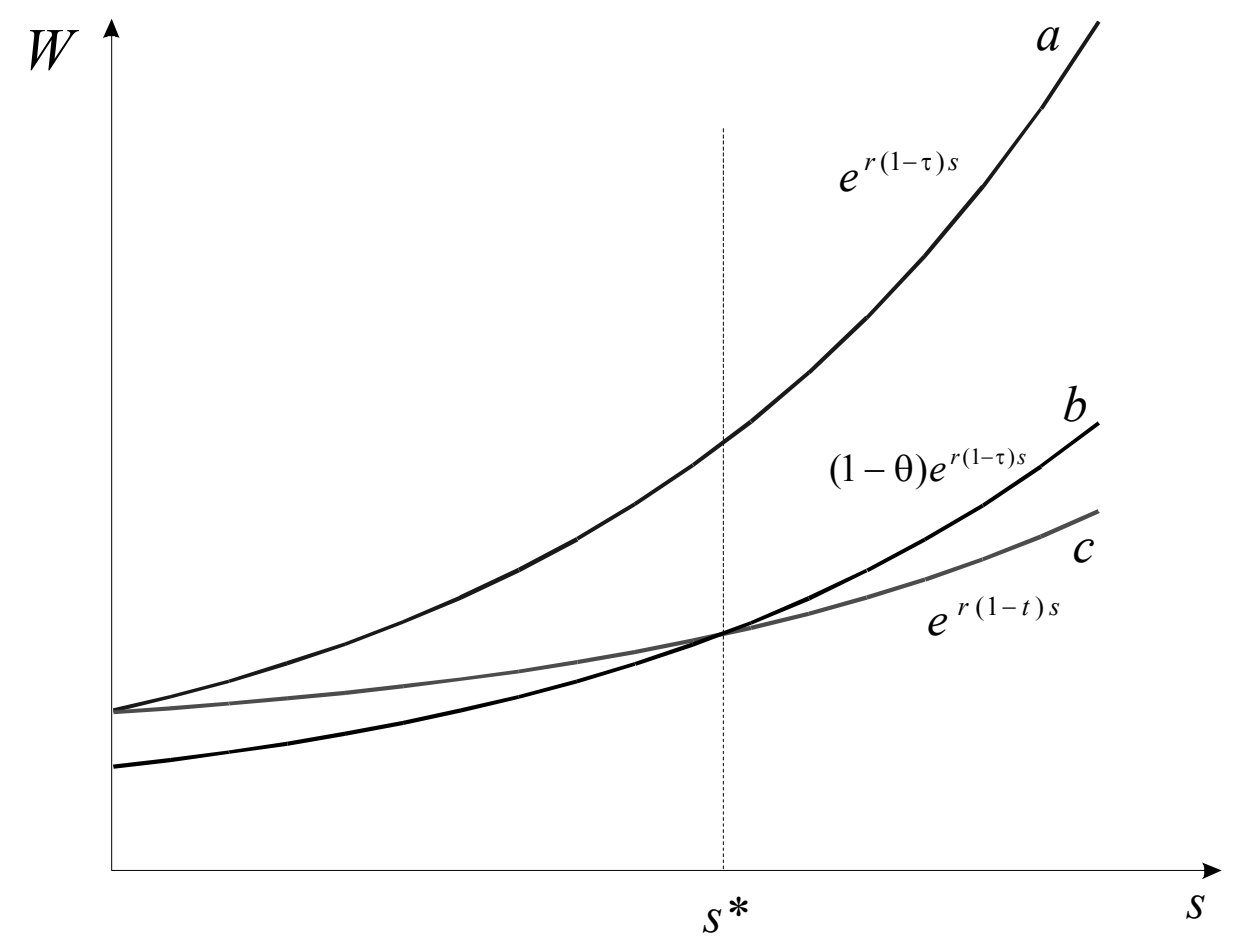

Note however, that, while private post-tax revenues are ready for consumption after selling the bonds, distributing corporate profits to shareholders in order to make them available for private consumption may come at a tax cost. If private savers and corporations have access to the same bonds and the same capital market return, then the corporate tax shelter can be 
beneficial even when high taxes on the distribution of corporate dividends apply. Assume that only a fraction $(1-\theta)<1$ of any Euro distributed by the corporations accrues to the owners of the corporation. This corresponds to a situation in which owners receive only a partial imputation credit for taxes paid at the corporate level. (In a classical corporate tax system, in which there is a full double taxation of corporate profits on the corporate and personal level, $1-\theta$ would approach $(1-t)$ as the weight of the initial Euro invested in the firm goes to zero. ${ }^{6}$ ) If we take into account that there is a tax cost to distributions, then this cost will capitalize in the value of corporate assets $W$ and decrease the path from level $a$ to a fraction $1-\theta$ times $a$. Notwithstanding this downshift, there is some finite investment period $s^{*}$, which makes it worthwhile to invest on path $c$ instead of $b$. Taking logarithms yields for the wealth levels on path $a, b$ and $c$

$$
\begin{aligned}
& \ln \left(W_{a}(s)\right)=r(1-\tau) s \\
& \ln \left(W_{b}(s)\right)=\ln (1-\theta)+r(1-\tau) s \\
& \ln \left(W_{c}(s)\right)=r(1-t) s
\end{aligned}
$$

Using (1) we can solve for the time $s$ that is required to make $W_{b}$ larger than $W_{c}$. Hence, final wealth is larger under path $\mathrm{b}$ than under $\mathrm{c}$ if for $\tau<t$

$$
\ln (1-\theta)+r(1-\tau) s>r(1-t) s \Leftrightarrow s>\frac{-\ln (1-\theta)}{r(t-\tau)}
$$

For example, with $\tau=0.3, t=0.5, \theta=0.18, r=0.1$ it takes an investment horizon $s$ of approximately 10 years to make the use of the corporate shelter worthwhile.

An essential part of determining $s^{*}$ is the cost (implied by a $\theta>0$ ) to make accumulated corporate profits available for private consumption. This cost seems to be particularly high in classical corporate tax systems that imply a high tax on dividend distributions. But even in classical corporate systems there are ways around the tax penalty on distributions.

\footnotetext{
${ }^{6} \theta$ will not exactly match $t$, since the initial Euro invested in the corporation could be plugged back costlessly.
} 
One way to reap cash benefits from a corporation's accumulated income without paying the dividend tax is to sell shares to other investors. To close that loophole, many countries charge a realization based capital gains tax. If raised at the same rate as the dividend tax rate, there is no tax benefit to shareholder in cashing in sales revenues instead of dividend income. However, reasons there are plenty why the loophole is all but closed. First, in many countries (such as Germany) capital gains are exempt if the personal shareholder's fraction in the corporation is small enough. In other countries, like in the U.S., capital gains are taxed at a lower rate or can be evaded in case of a bequest.

Share repurchases are a similar way to reap cash benefits without paying dividend taxes. For example, in the U.S. the fraction of corporate profits that have been distributed as share repurchases has been estimated to amount to more than 50 percent of dividend payments in the late 80 's. ${ }^{7}$ Like in the case of share sales to other investors, proceeds to personal investors are subject to capital gains taxes but exempted from ordinary income tax.

From the above, it is clear that it is all but a straightforward thing to estimate the actual $\operatorname{cost} \theta$ as a function of the corporate tax system and the stringency of capital gains taxes. So in order to derive testable empirical implications, the next section will take a slightly different approach to the problem.

\section{A Simple Model of Income Shifting}

While the above discussion has made clear that the difference in personal and corporate tax rates plays a role in the allocation of savings between the corporate and non-corporate sectors, it is helpful to further fix ideas and to develop empirically testable hypotheses before we proceed to the empirical part of the paper. We do so by setting up a simple model that incorporates optimizing behavior of firms and personal investors in the face of different tax rates on different types of income.

\footnotetext{
${ }^{7}$ See Bagwell and Shoven (1989).
} 
Consider a stylised model of a small open economy where two types of income shifting may occur. Firstly, domestic households may shift income from savings between the personal and the corporate base. Secondly, firms may shift income from domestic investment to other countries. Of course, the existence of these two types of income shifting raises the question whether taxpayers can shift income directly from the personal sphere to a foreign corporation, which is located in a low tax country. We rule out this possibility. Note that most OECD countries have incorporated sections into their national tax codes that from a tax planning point of view make it difficult or less worthwhile to set up a passive-investment corporation abroad. ${ }^{8}$ Increased international co-operation may add to the problems of using such vehicles for tax planning of private households.

The interest rate by assumption is fixed to the international level $r$. There is a representative household who owns an incorporated firm. The household lives for two periods. In the first period, the household decides on the amount of saving, $S$, on the fraction $\pi$ of $S$ that is held in the private portfolio, and on the fraction $(1-\pi)$ that is saved via domestic corporations. Income earned in the domestic corporation may be shifted to a foreign subsidiary. The amount of corporate income shifted abroad is denoted by $\beta$.

The effective tax rate on corporate returns is denoted by $\tau$, the tax rate on returns of privately held portfolios is $t$ and the effective tax rate on foreign corporate income is $\tau *$. Allowing for an initial endowment of $A$, and assuming that both private portfolios and corporate investment will yield the worldwide pre-tax return $r$, the household budget constraint is given by

$$
\begin{gathered}
C_{1}=A-S \\
C_{2}=\pi S[1+r(1-t)]+(1-\pi) S[1+r(1-\tau)]+T-\psi(\pi) \cdot S+\left(\tau-\tau^{*}\right) \beta-\gamma(\beta),
\end{gathered}
$$

where $\psi(\pi)$ is a strictly convex cost function with a minimum at some $\pi^{*}: \psi^{\prime}\left(\pi^{*}\right)=0$. The function captures possible pros and cons of investing via the corporate sector that lie outside

\footnotetext{
${ }^{8}$ See Weichenrieder (1996a, 1996b) for an analysis of the so-called Subpart-F type legislation.
} 
the tax sphere. ${ }^{9}$ The function $\gamma(\beta)$ captures the cost of shifting income to the foreign subsidiary. Intuitively, the larger the amount of profits shifted, the larger are the necessary efforts to cover up such behavior. ${ }^{10}$ We assume that $\psi(\pi)$ and $\gamma(\beta)$ are strictly convex. $T$ is the tax revenue of the government that by assumption is handed back to the household on a per capita basis:

$$
T=\pi s r t+(1-\pi) s r \tau-\tau \beta
$$

Merging the two budget constraints into one gives

$$
\begin{gathered}
C_{2}=\pi\left(A-C_{1}\right)[1+r(1-t)]+(1-\pi)\left(A-C_{1}\right)[1+r(1-\tau)] \\
+T-\psi(\pi) \cdot\left(A-C_{1}\right)+\left(\tau-\tau^{*}\right) \beta-\gamma(\beta)
\end{gathered} .
$$

The household uses the instruments $C_{1}$ and $\pi$ to maximize $U\left(C_{1}, C_{2}\right)$. The first order conditions read:

$$
\begin{gathered}
\frac{\partial U}{\partial C_{1}}-\frac{\partial U}{\partial C_{2}}\{\pi[1+r(1-t)]+(1-\pi)[1+r(1-\tau)]-\psi(\pi)\}=0 \\
\frac{\partial U}{\partial C_{2}}\left\{s[1+r(1-t)]-s[1+r(1-\tau)]-r s \psi^{\prime}\right\}=0 .
\end{gathered}
$$

At the same time, optimization of the corporation in the best interest of its domestic owner leads to

$$
\frac{\partial U}{\partial C_{2}}\left\{\left(\tau-\tau^{*}\right)-\gamma^{\prime}\right\}=0
$$

Assuming positive marginal utility of second period consumption, we have from condition (3) that the fraction of savings in the personal portfolio is a function of the difference in the corporate and personal tax rates:

$$
\psi^{\prime}(\pi)=r(\tau-t) \Rightarrow \pi=\pi(\tau-t)
$$

\footnotetext{
${ }^{9}$ See Gordon and MacKie-Mason (1994) for empirical estimates of the non-tax cost of incorporating or nonincorporating.

${ }^{10}$ Since interest rate $r$ is exogenously given, it would be equivalent to include it as an argument in the cost function.
} 
It is worth emphasizing that the optimal share of savings channeled to the private and corporate sectors is a function of the difference in effective tax rates but it is not a function of total tax revenues collected by the government. This of course is not to say that tax revenues are independent of $\pi$. The third first order condition in equation (4) implies that the amount of income shifted to the foreign country is $\beta=\beta\left(\tau-\tau^{*}\right)$, with $\beta^{\prime}=1 / \gamma^{\prime \prime}>0$.

Taken together, the simple model above leads to the intuitive results that the shifting of income between the personal and the corporate sphere is a function of the difference in domestic personal and corporate tax rates. This function will be the focus of our empirical analysis in section 6 .

From equation (4), the income shifting between the domestic and the foreign branches of a corporation depends on the differences in the domestic and the foreign corporate tax rate. This type of shifting, as we will consider in greater depth in the next section, has interesting implications for countries' tax setting policies.

\section{Optimal National Tax Policies in the Face of Income Shifting}

Given the reactions of private firms and investors described above, what is the optimal national tax policy in this framework? In order to facilitate the presentation of the optimal tax policy analysis, we assume $U\left(C_{1}, C_{2}\right)=g\left(C_{1}\right)+C_{2}$, with g' $>0$, g' $<0$. That is the houshold's utility is quasi-linear in second period consumption, so that $\partial U / \partial C_{2}$ is constant. This assumption implies that we abstract from income effects on the level of savings. The government maximizes the household's utility subject to the tax revenue requirement $T=\pi s r t+(1-\pi) s r \tau-\tau \beta$.

The Lagrangean can be written as

$$
\Omega(t, \tau, \eta)=g\left(C_{1}\right)+C_{2}+\eta(\pi s r t+(1-\pi) s r \tau-\tau \beta)
$$

The first order conditions read 


$$
\Omega_{t}=(\eta-1) r s \pi+\eta(\pi t+(1-\pi) \tau) r \frac{\partial s}{\partial t}=0
$$

$$
\Omega_{\tau}=(\eta-1)(r s(1-\pi)-\beta)+\eta\left[(\pi t+(1-\pi) \tau) r \frac{\partial s}{\partial \tau}-\tau \frac{\partial \beta}{\partial \tau}\right]=0
$$

Can a policy of equal corporate and personal income tax rates be optimal? Evaluating the above first order conditions at $t=\tau$ and using $\partial s / \partial t=(\partial s / \partial \tau) \pi /(1-\pi)$, which follows from equation (2), we have

$$
\Omega_{\tau}=-(\eta-1) \beta-\eta \tau \frac{\partial \beta}{\partial \tau}<0
$$

Clearly, according to our model a country would not wish to equate personal and corporate tax rates. The reason is intuitive. While an increase in the domestic corporate tax rate leads to additional income shifting from the home country to the foreign country, an increase in the personal income tax rate leads to a shift between domestic tax bases. So the first type of income shifting is much more costly to the national government. Hence we expect a higher reluctance to have high corporate tax rates. ${ }^{11}$

\section{The Development of Tax Rates: Some Empirical Observations}

The theoretical analysis in the preceding section predicts that corporate tax rates - from the perspective of optimizing governments - should be lower than personal tax rates. It is important to note that this result has been derived under the assumption that the residence principle of household taxation can be perfectly enforced and the domestic tax rate on savings, $t$, is indeed collected. In reality this is certainly extremely doubtful and, as highlighted in the introduction, the contrary belief has led to the proposal of detailed EU policies in this area.

\footnotetext{
${ }^{11}$ A reduction of the corporate tax below the personal income tax rate may also be an optimal policy in the presence of asymmetric information in capital markets (see Fuest et al. (2001)). The opportunities of multinationals to shift income across borders and the consequences of this for international tax competition has recently been highlighted by Haufler and Schjelderup (2000).
} 
Figure 2: The Average Difference between Top Personal and Corporate Tax Rates

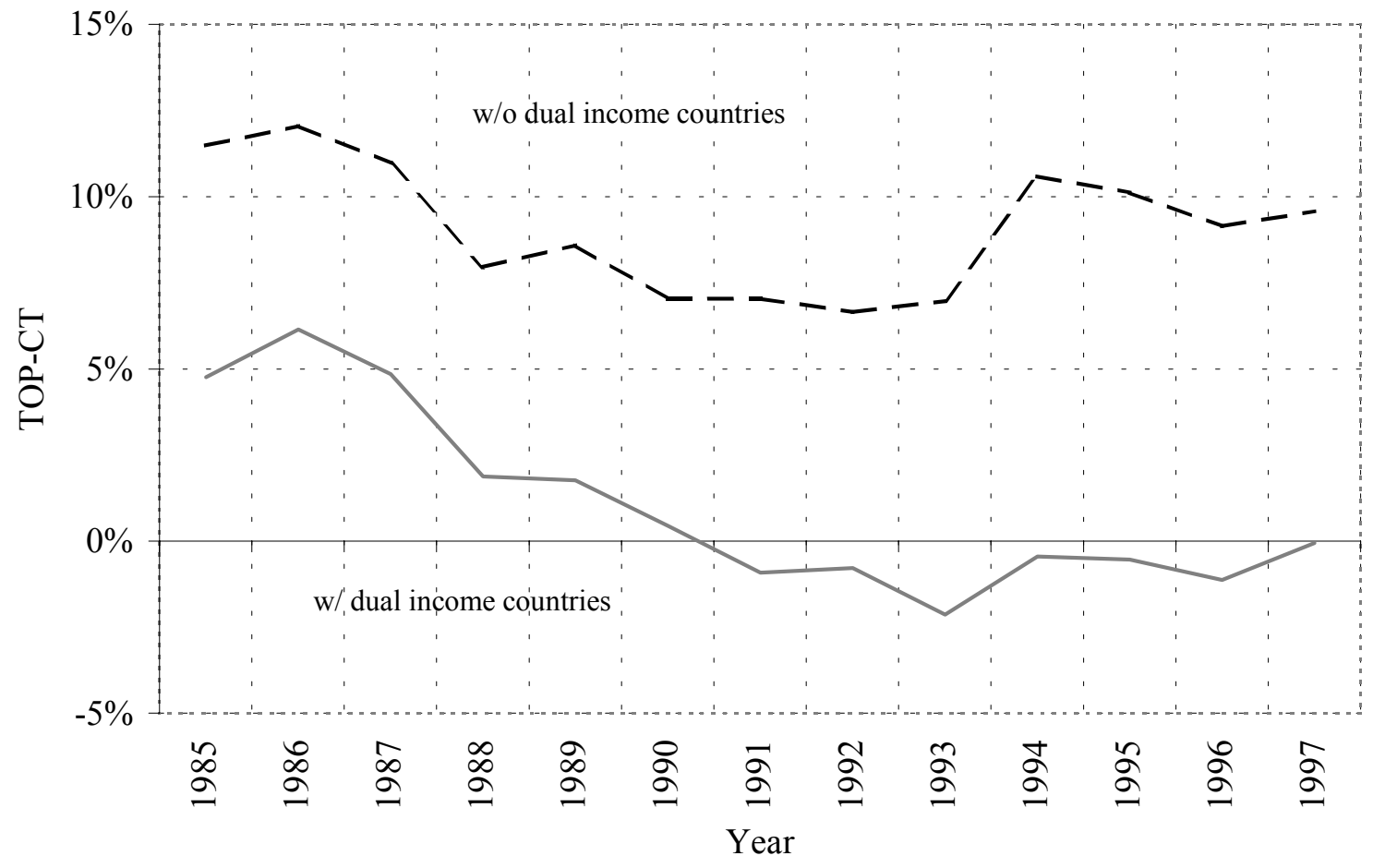


Annotations: The graph shows two averages over time for two different sets of OECD countries. The solid line plots the average difference of the corporate tax rate and the personal tax rate on interest income for Australia, Belgium, Canada, Switzerland, Czech Republik (1993-1997), Germany, France, Spain, Finland, UK, Italy, the Netherlands, Norway, Sweden, and the U.S. The dashed line excludes all those countries that have introduced separate tax rates for interest income and labor income, i.e., Belgium, Finland, France, Sweden, Italy, Japan, and Norway. In both cases, the plots are based on a comprehensive measure of CT and TOP, including typical local and federal surcharges.

Against the background of the model, a look at the recent history of tax policy changes in OECD countries is tempting. To analyze these changes, we have tried to measure tax rates in a comprehensive manner. So unless indicated differently, corporate tax rates in this paper are for retained earnings and include typical local taxes plus surcharges. Personal tax rates are rates that apply to interest income and also include local taxes. Based on those comprehensive rates, the solid line in Figure 2 indicates that on average the difference between personal tax rates and corporate tax rates has come down and indeed has turned slightly negative. This, however, is far from being a universal observation. The dashed line excludes countries with dual income tax systems, which imply a flat rate on interest income. It turns out that most countries with a progressive taxation of interest income continue to employ a tax rate on personal income that exceeds the tax on corporate income. 
Figure 3: Cuts in Personal and Corporate Tax Rates

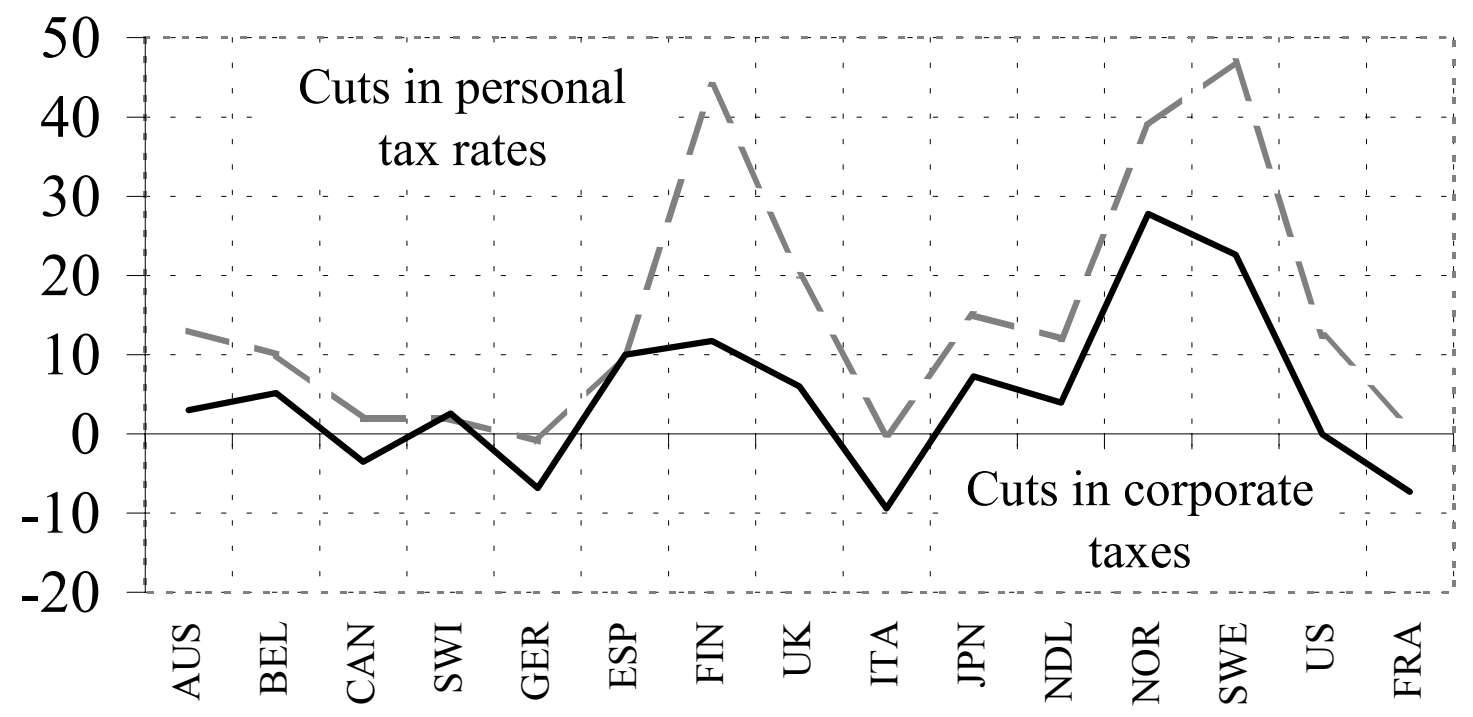

Annotations: Figure 3 depicts the changes in personal and corporate taxes from 1985 to 1997 . The solid line shows the percentage point cuts in corporate taxes on retained earnings between 1985 and 1997. The dashed line shows the cuts in the top personal tax rate on interest income. Hence the difference between the dashed and the solid line shows how the difference between the comprehensive top marginal income tax rate on interest income (TOP) and the corporate tax rate (CT) has evolved over time. 
Figure 3 illustrates the development of the tax rates for 15 OECD countries. The solid line shows the percentage point cuts in corporate taxes between 1985 and 1997 . The dashed line shows the cuts in the top personal tax rate on interest income. Hence the difference between the dashed and the solid line shows how the difference between the comprehensive top marginal income tax rate on interest income (TOP) and the corporate tax rate (CT) has evolved over time. Canada and Germany have been the only countries that have experienced an increase in the corporate tax during the period. And all countries but Switzerland have experienced personal tax cuts that have been more pronounced than corporate tax cuts. ${ }^{12}$

The fact that corporate taxes, by and large, have come down by much less than personal tax rates on capital income contrasts with the model developed in sections 3 and 4 . This model suggests that a reason for having a CT that undercuts TOP is the international profit shifting that is induced by high corporate tax rates. If the importance of this phenomenon has increased, then we should expect that TOP-CT is widening rather than shrinking. As mentioned above, such a conclusion would overlook, however, that we cannot readily assume that, during the observed period, the residence-based system of taxing interest income was perfectly enforced. High income tax rates not only drive savings under the corporate shelter but also to foreign banks. If this type of tax competition proves even more severe than the corporate profit-shifting problem, then the empirical observations above are perfectly reasonable. This does not imply that having a low corporate income tax rate does not open another interesting loophole for private savers. After all, unlike tax evasion, the use of a corporate shelter to protect capital income against a high TOP is a perfectly legal thing to do.

Indeed there is evidence that tax competition has been more severe for TOP than for CT. One well-known prediction of standard tax competition models (see, e.g., Wellisch 2000 or Kanbur and Keen (1993)) is that smaller countries have a stronger incentive to lower their tax rates. Evaluated against this background, competition seems to have been much more effective for personal tax rates than for corporate tax rates. Figure 4 shows the correlation

\footnotetext{
${ }^{12}$ It should be mentioned that five countries (Belgium, France, Germany, Italy and Japan) started out with a negative difference of TOP-CT in 1985 that still was present in 1997.
} 
between corporate tax cuts and country size, as measured by the log of 1995 population. While a negative correlation is present, a linear regression of the decrease in corporate tax rates on country size is not significant.

Figure 4: Corporate Tax Cuts and Country Size.

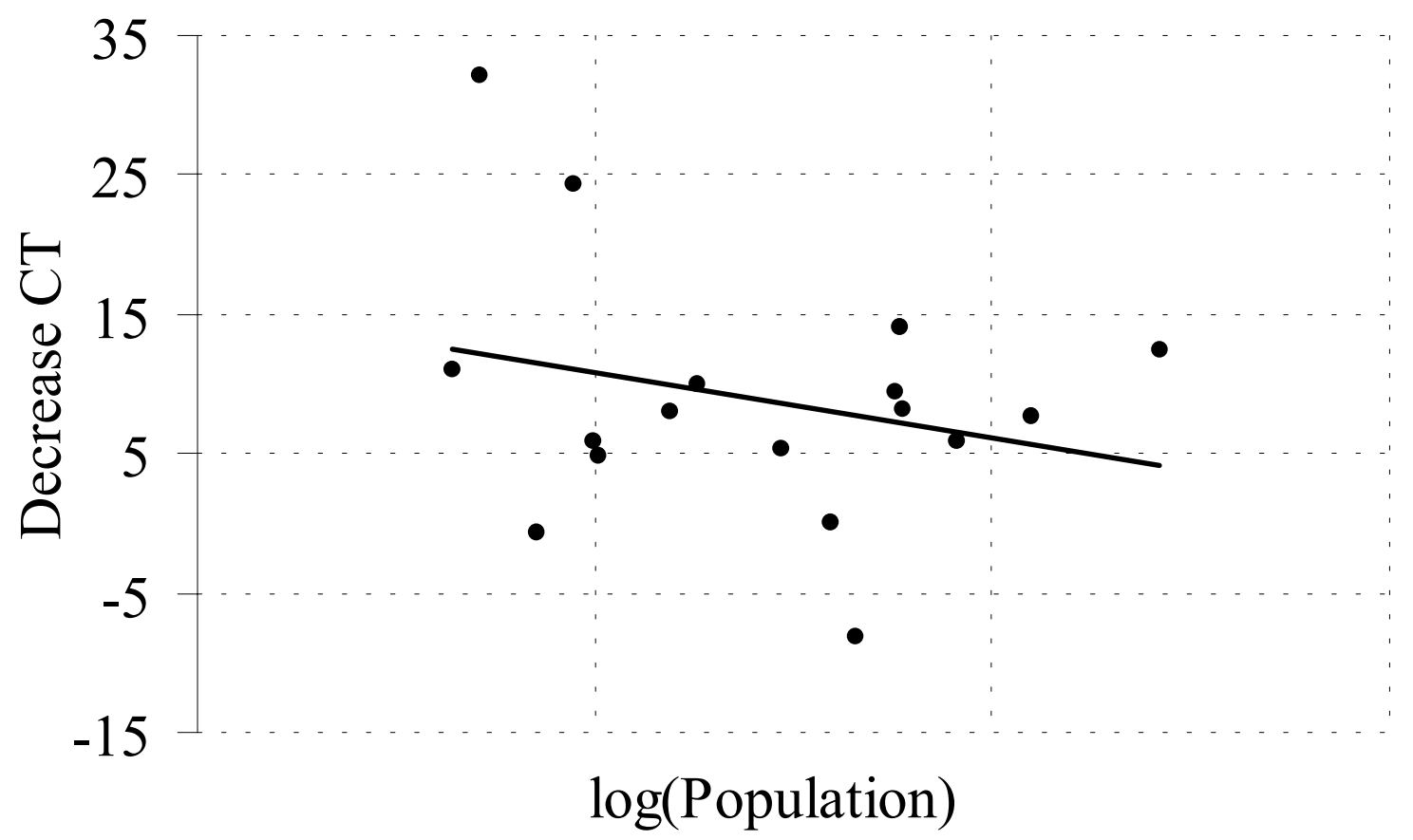

Annotation: The figure shows the drop in corporate tax rates (measured in percentage points) between 1985 and 1997. The set of countries includes Australia, Belgium, Canada, Switzerland, Germany, Finland, Spain, France, UK, Italy, Japan, Korea, the Netherlands, Norway, Portugal, Sweden, and the U.S.

As indicated by Figure 5, the negative correlation between the cut in top personal tax rates and country size is much stronger. For our sample of countries a simple linear regression of the cuts in corporate tax rates on the $\log$ of population shows a negative correlation that is significant at the 5 percent level. 
Figure 5: Personal Tax Cuts and Country Size.

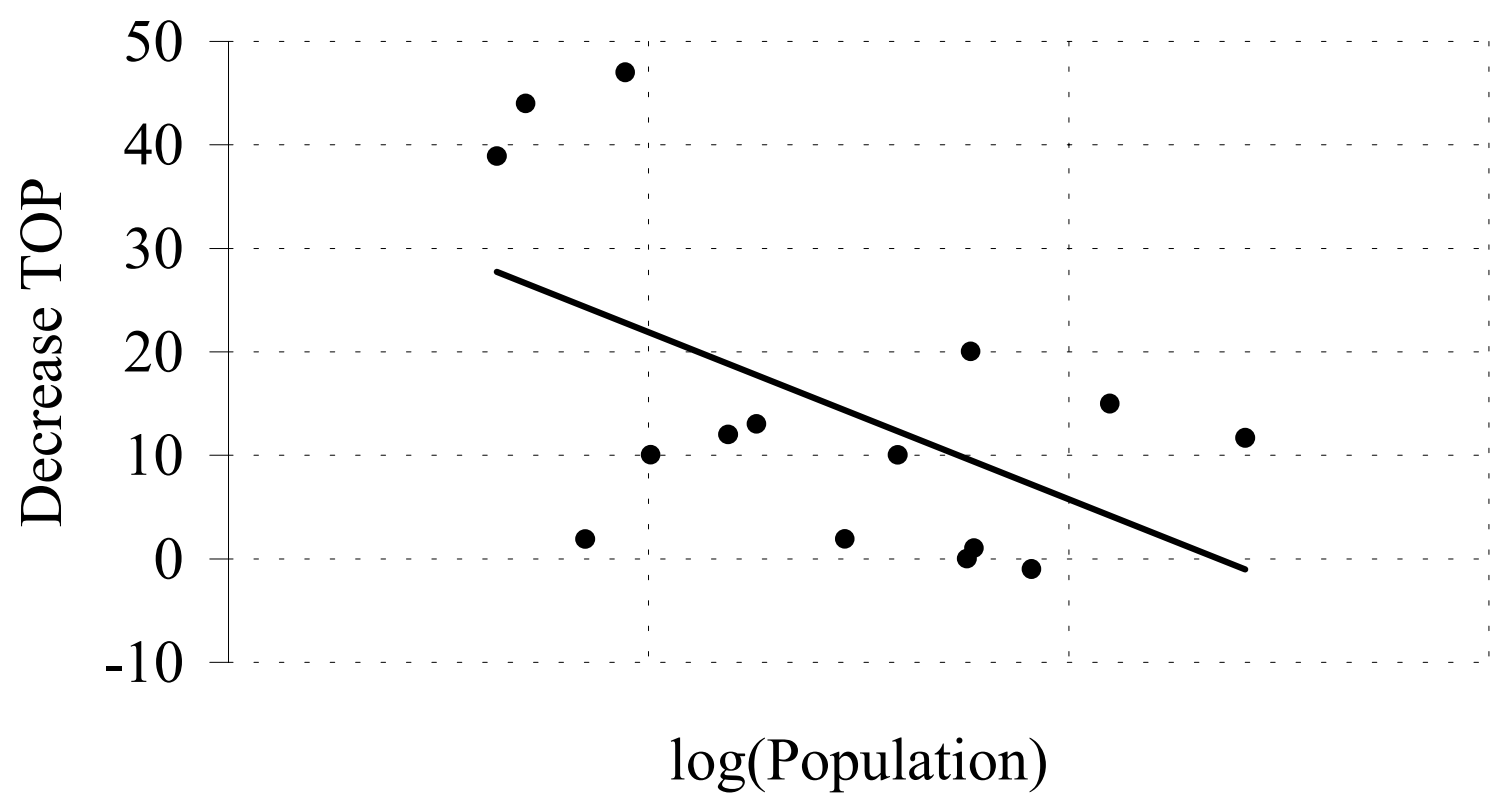

Annotation: The figure shows the cuts in top personal tax rates on interest income (measured in percentage points) between 1985 and 1997. The set of countries includes Australia, Belgium, Canada, France, Switzerland, Germany, Spain, Finland, UK, Italy, Japan, the Netherlands, Norway, Sweden, and the U.S. 


\section{Empirical Analysis}

The theoretical considerations in sections 2 and 3 suggest that we should expect the allocation of savings between the corporate and non-corporate sector to be driven at least partly by the difference in the income tax rates in those sectors. In the following we want to empirically evaluate the size of this effect.

Since the seminal work of Harberger (1966), tax policy and its influence on the division of economic activity between the corporate and non-corporate sector have received large attention in the literature. But empirical analysis on the allocation of assets or savings between the corporate and the non-cooperative sector as to the best of our knowledge is extremely sparse and are restricted to U.S. time series. In this vein, Mackie-Mason and Gordon (1997) empirically analyze the post-WWII U.S. time series (1959-1986) for personal tax rates, corporate tax rates and the distribution of assets between corporations and non-incorporated firms. They find rather modest tax effects. According to their estimates, a 10 percent increase in the personal income tax rate leads to an increase in assets in the corporate sector by 0.2 percent. Goolsbee (1998) uses a similar methodology and applies it to historical time series between 1900 and 1939. The effects of tax changes on asset allocation again turn out to be statistically significant but small.

The following analysis differs from those cited in several respects. First, we use a panel set for 13 OECD countries. Second, instead of taking as an endogenous variable total assets in the corporate or the non-corporate sector we look at the savings as measured by national accounts data. Third, unlike existing studies we find sizeable tax effects.

Data on savings in the corporate and non-corporate sector are available from the National Accounts of the OECD Statistical Compendium for a subset of OECD countries. As a first step, we construct the variable PRIVCORP that is defined as the fraction of the share of corporate savings in total private savings, i.e. the ratio of corporate savings over corporate plus non-corporate savings. It is a natural candidate to serve as a proxy for $(1-\pi)$ in the model of section 3. Figure 6 shows the development of the variable for 15 OECD countries 
for which we could collect a comprehensive and reliable set of tax rates and for which the required savings data is available. Excluding Finland and Sweden, the average fraction of savings that occurs within corporations across time and countries equals 32 percent. As the graph shows, however, Finland and Sweden show exceptional and not directly plausible values for PRIVCORP at least for part of the sample period. For Finland the fraction of savings within corporations ranges from -900 to +700 percent. Similarly, for Sweden the value of up to 2500 percent for PRIVORP is certainly not linked to tax policy but is due to some structural break or data problem. We therefore decided to drop these two countries and did not force the empirical model to explain these extreme outliers. 
Figure 6: The Variable PRIVCORP
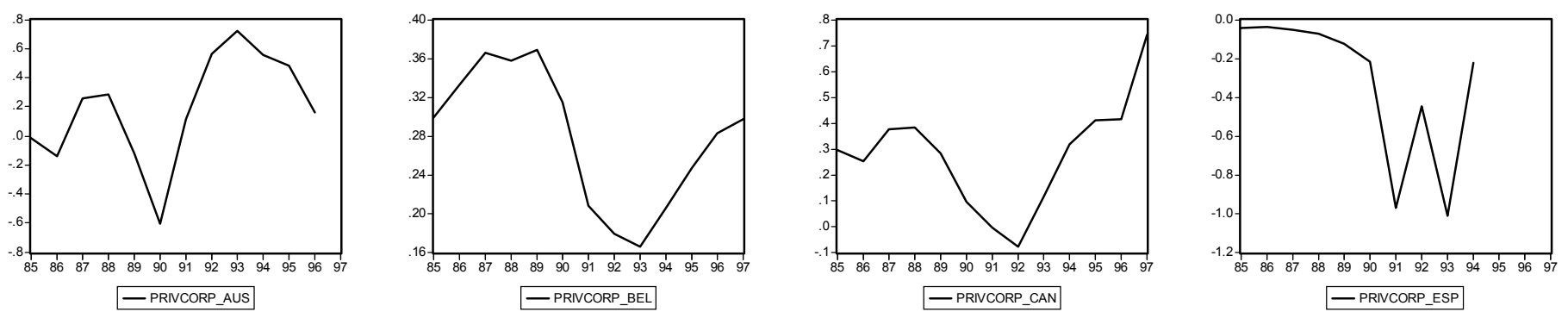

-PRNCORP_BEL
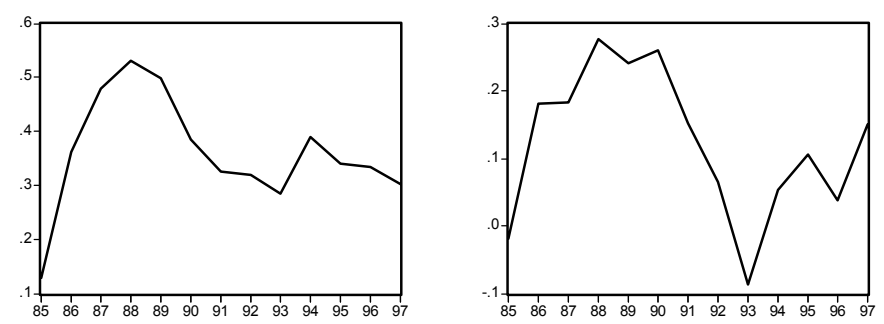

-PRNCORP_CAN

- PRNCORP_ESP

- PRNCOPP.FRA
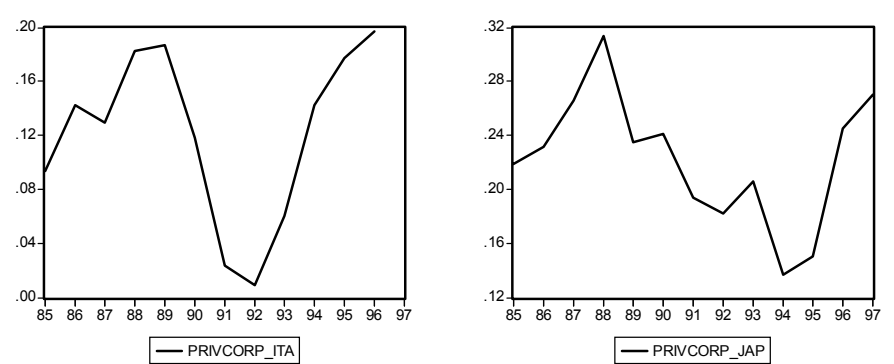

-PRNCORP_GER
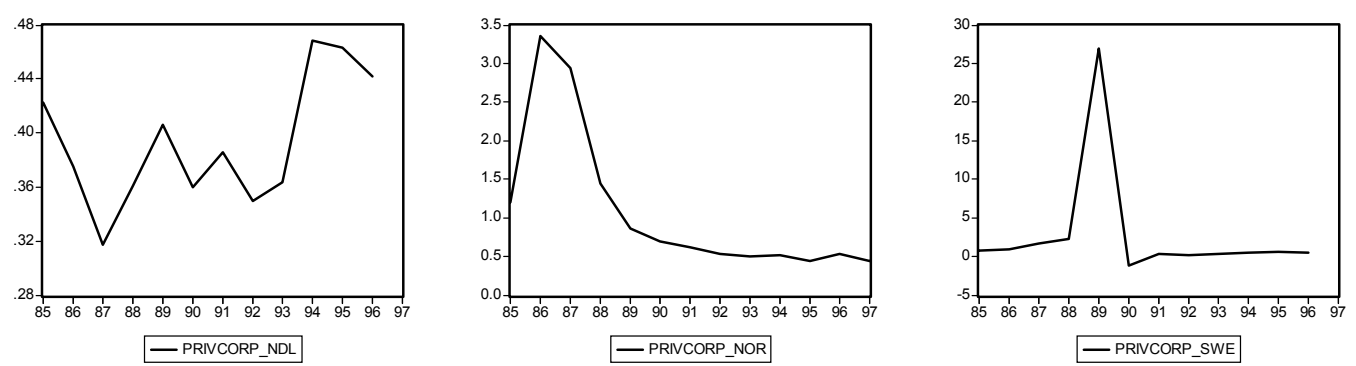

- PRINCORP_AAP
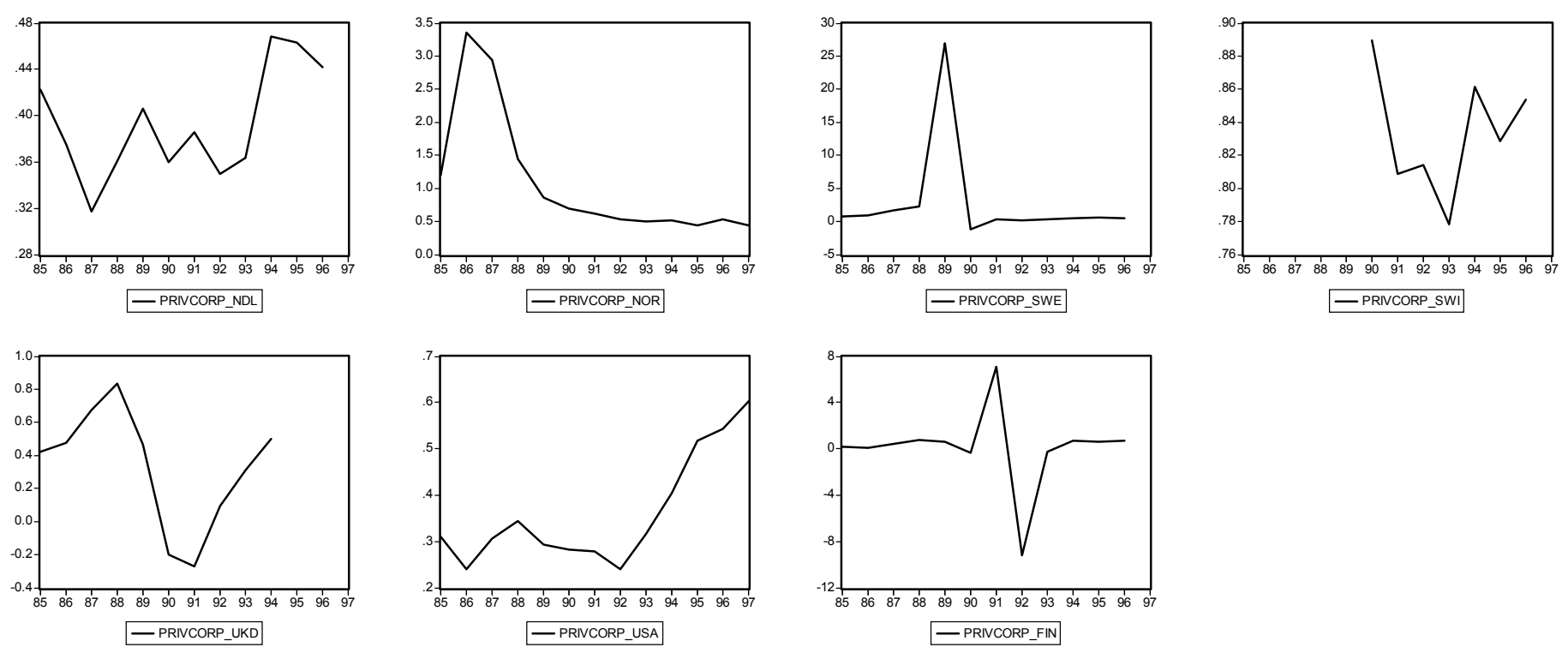
Figure 7: The Difference in Top Personal and Corporate Tax Rates (DIFF)
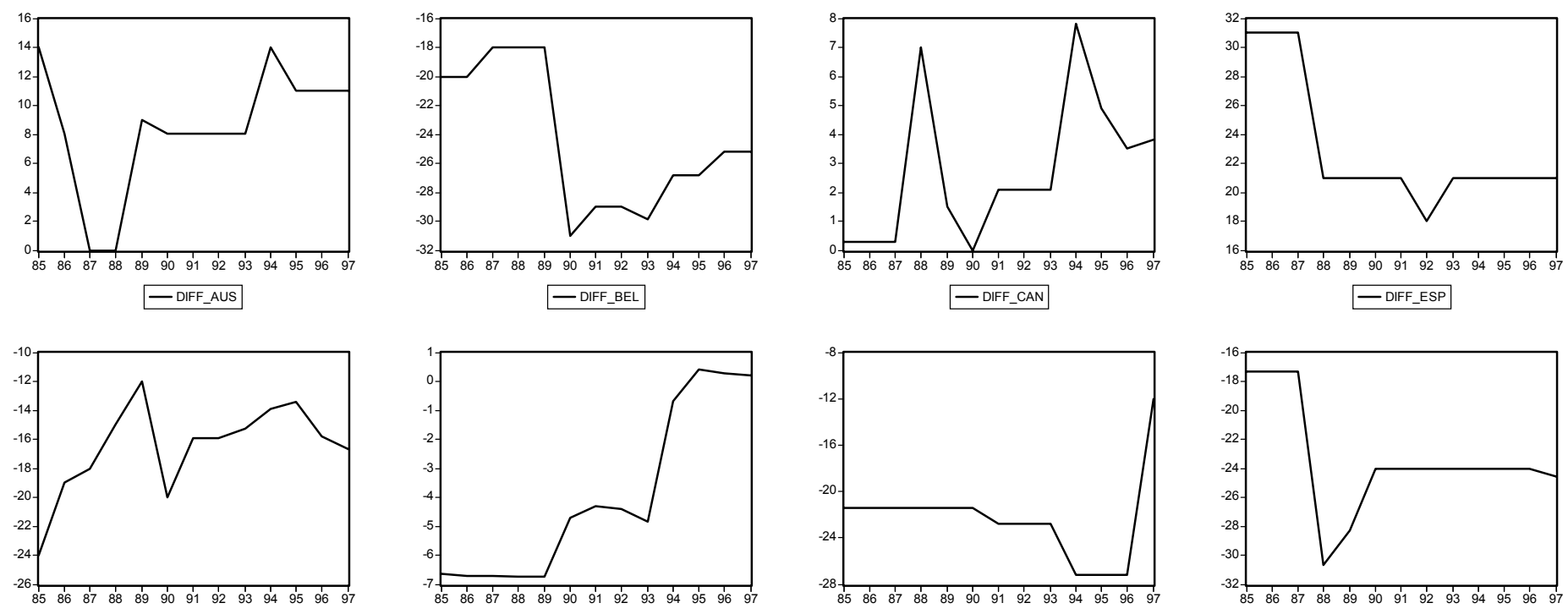

- DIFFFRA

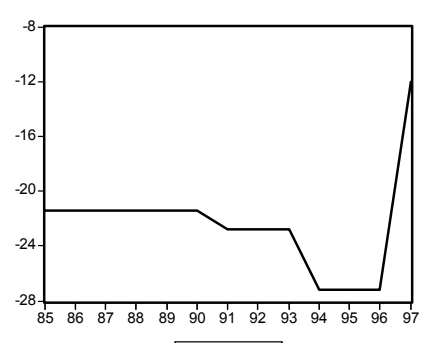

一DIFF_ESP
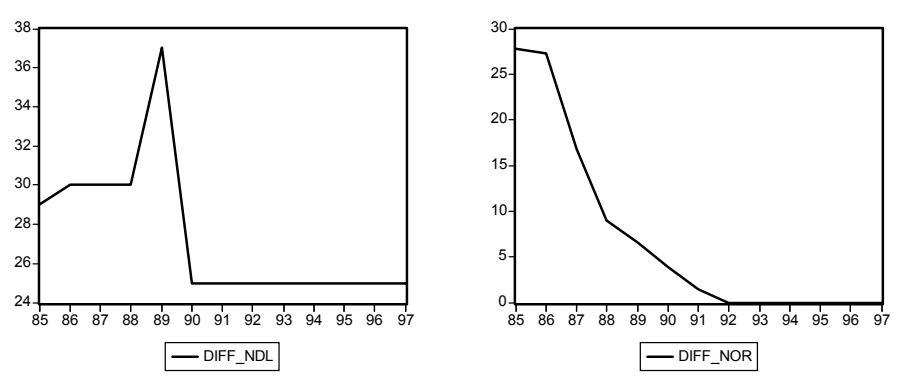

一DIF_ITA

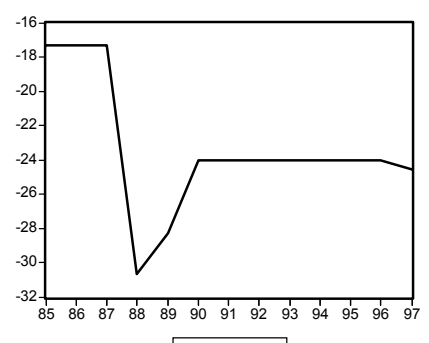

-DIF_JAP
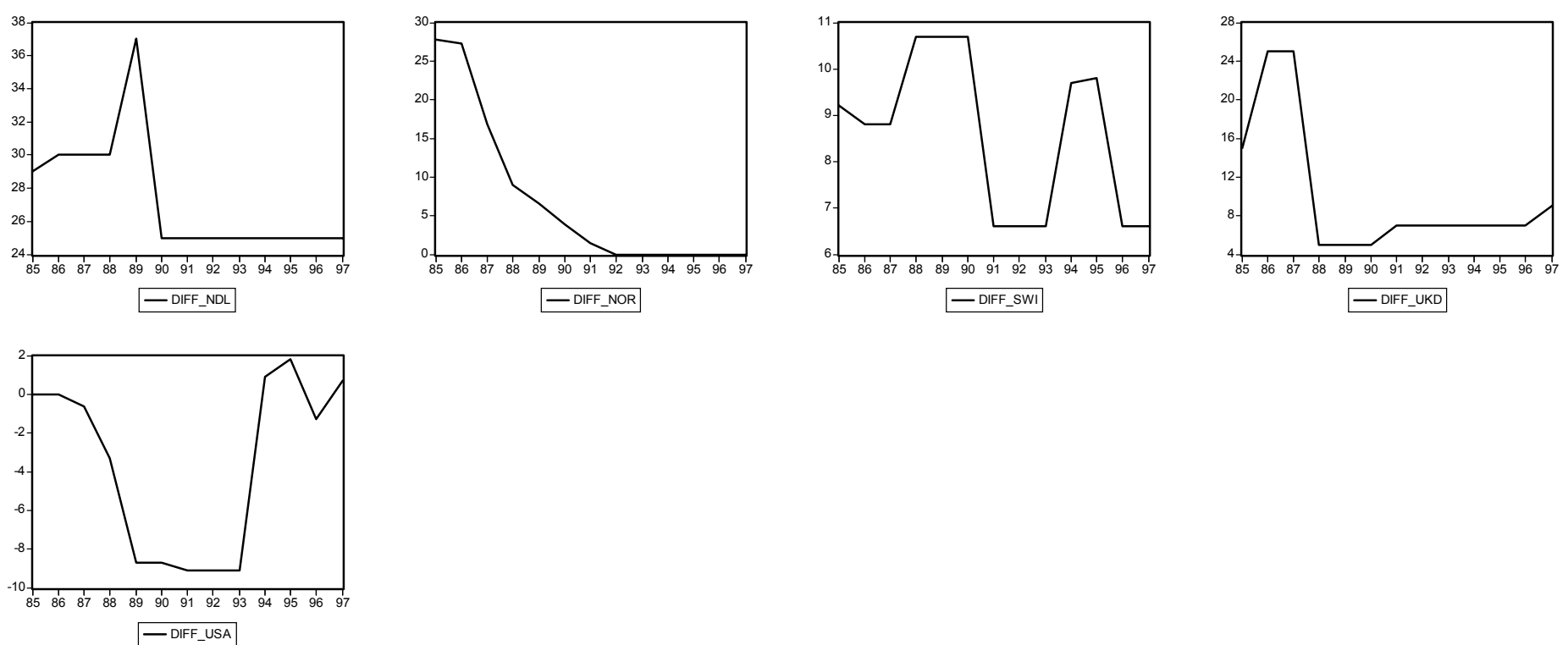
Non-corporate savings include the savings of unincorporated firms and private households. Savings of corporations are defined as net-profits minus dividend distributions to the non-corporate sector. ${ }^{13}$ Profit distributions between corporations do not change savings in the corporate sector as a whole. Note that changes in the structure of corporate finance can affect the measure of corporate savings. An increase in corporate debt in the form of pension obligations reduces corporate savings and increases private savings. More generally, a tax system that favors debt may lead to less profits after taxes and interest and therefore to less savings within corporations. This contrasts with the studies of U.S. data by MackieMason/Gordon (1997) and Goolsbee (1998) that consider tax effects on the share of assets held in corporations, but that do not measure any financing effects. Since we are interested in tax competition issues, including financing effects indeed is appropriate. Evaluated against the theoretical tax shifting background developed in the previous chapters, if one effect of a lower corporate tax rate is that it induces corporations to increase their savings via a reduction of debt finance, we are certainly interested in this. ${ }^{14}$

Our measure of the difference in personal and corporate tax rates ("DIFF") relies on comprehensive rates, including typical local taxes and federal and sub-federal surcharges. For the personal tax rate we employ the rate for top income receivers. In the case of different rates on different types of income we use the rate applicable to interest income. ${ }^{15}$ Figure 7 gives an impression of how this difference has involved over time in different countries. Confer to the appendix for the complete set of tax rates used.

\footnotetext{
${ }^{13}$ This creates the possibility of negative corporate savings if distributions, which may be financed by past earnings, exceed net current profits.

${ }^{14}$ Share repurchases, however, do not affect the corporate savings measure. While this is not ideal for our purposes, it seems to be a cost that has to be paid if national accounts data on savings is used.

${ }^{15}$ Taking the set of countries included in Figure 6 and Figure 7, a different treatment of labor and interest income applies in Belgium, Finland (since 1993), France, Italy, Japan, Norway (since 1992), and Sweden (since 1991).
} 
Table 1: Tax Effects on Corporate Savings

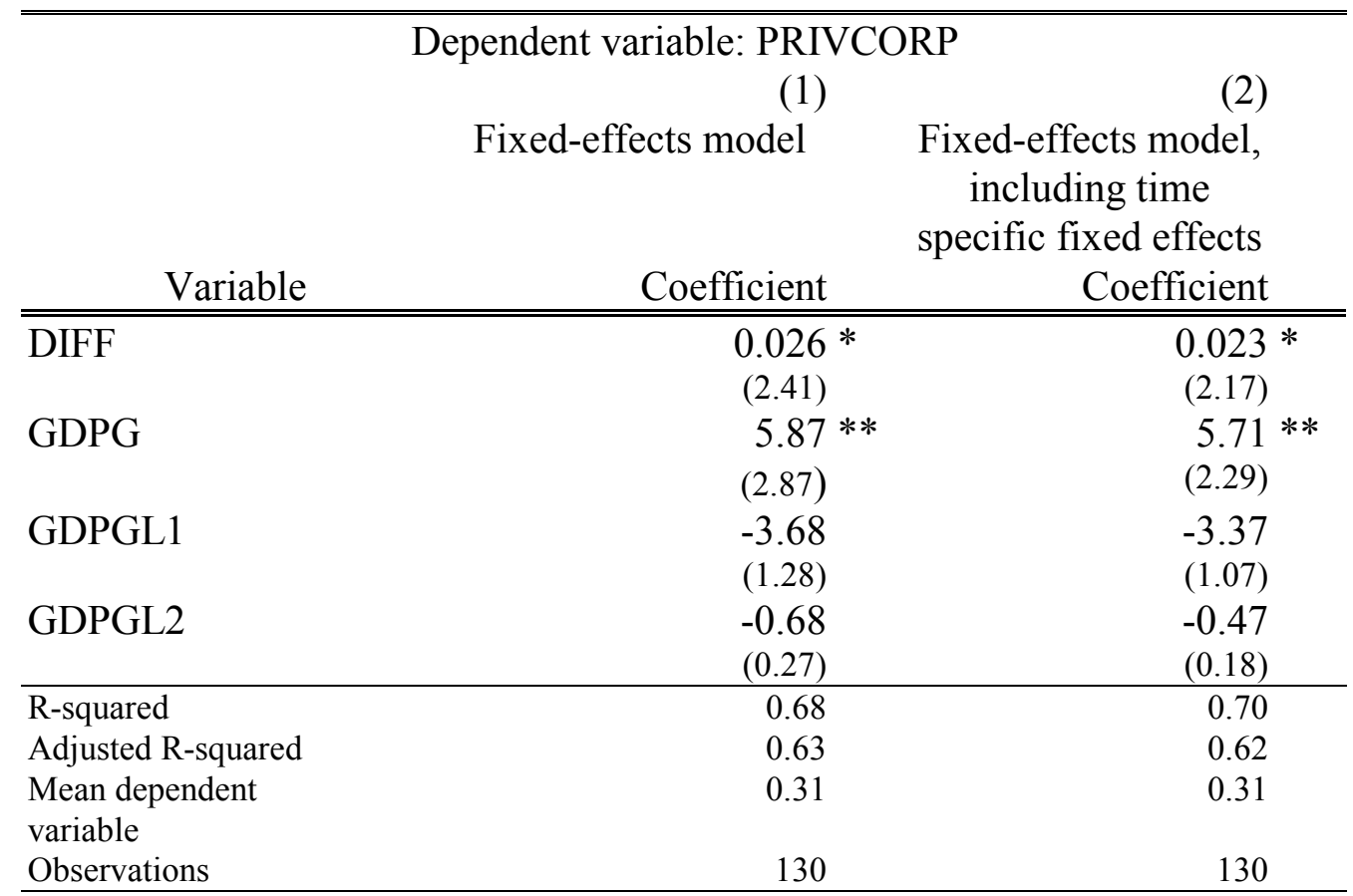

\begin{abstract}
Annotation: Estimation based on 13 countries. $* * / *$ indicate significance at the 1 and 5 percent level, respectively. Absolute t-values are given in parenthesis. All significance levels are based on White-corrected standard errors. Individual country dummies and time specific effects in model (2) are not reported. The hypothesis that the coefficients for GDPGL1 and GDPGL2 are both zero can be rejected at the one percent level for model (1) and (2).
\end{abstract}

Assuming that investors consider today's tax rates to decide on their composition of savings we estimated models that try to explain the fraction of savings in the corporate sector, PRIVCORP, by the current difference in the top personal tax rates on interest and the corporate tax rate, DIFF. Additionally we use the growth rate of nominal GDP, GDPG, to correct for cyclical sensitivity of corporate profits and retentions. Since high growth rates tend to favor corporate profits, we expect that a high current value of GDPG should lead to high profits. If distribution of dividends follows corporate profits with some lag, this should increase corporate retentions and therefore corporate savings. Conversely, if past profits have been high, this may lead to high distributions today even if current profits are low. This 
suggests that lags of GDPG (GDPGL1, GDPGL2) may have a negative impact on PRIVCORP.

Table 1 reports our estimation results. Model (1) reports a simple fixed effects model. The influence of the tax rate differential supports our theoretical model and is significant at the 5 percent level. According to the estimates, a one percent decrease in the corporate tax rate increases the fraction of corporate savings in total private savings by 2.6 percentage points. As expected, the current GDP growth significantly increases the fraction of corporate savings, and past GDP growth enters negatively. While neither GDPGL1 nor GDPGL2 is significant in itself, the hypothesis that both coefficients are jointly zero can be rejected at the 1 percent level.

Model (2) reproduces model (1) but includes time specific fixed effects to allow for common shocks across countries. Again the differential between the top personal and the corporate tax rates significantly influence savings decisions. According to model (2) a one percent decrease of the corporate tax rate can be expected to increase the fraction of corporate savings in total private savings by 2.3 percentage points. It should be noted though, that the time specific effects are not jointly significant.

\section{Concluding Remarks}

Our empirical estimates show that corporate savings seem to significantly react to tax incentives in OECD countries. The estimations in this paper suggest that a one percentage point increase in the tax rate on private interest income may increase the fraction of saving performed within corporations by some 2.6 percentage points. Seen from the perspective of tax competition, a reduction in the corporate tax rates may therefore shift significant amounts of savings from the household sector to the corporate sector.

This tax shifting behavior has potentially important implications for the plan to enforce residence-based taxation of savings through tax co-ordination in the EU. It may well be that this co-ordination closes the loophole offered by foreign bank accounts - although it is clear 
that tax havens outside the EU will continue to exist. But this type of co-ordination will not close the corporate tax shelter analysed in this paper. As a reaction to improved enforcement of residence based taxes on income from savings, our analysis suggests an increase in savings within the corporate sector. 


\section{Bibliography}

Altshuler, R., H. Grubert (2000), Repatriation Taxes, Repatriation Strategies and Multinational Financial Policy, Working paper, Rutgers University (forthcoming in: Journal of Public Economics).

Alworth, J.S. and L. Castellucci (1993), Tax Reform and the Cost of Capital - An International Comparision", in D.W. Jorgenson und R. Lanshan (eds.), Brookings, Washington, 191-243.

Alworth, J.S., G. Arachi, R. Hamaui, and R. Violi (2001) The taxation of income from capital in Italy: 1990-2001, paper presented at the CESifo/FuCam conference on "Capital taxation in the EU", October 2001.

Bagwell, L.S. and J.B. Shoven (1989), Cash Distributions to Shareholders, Journal of Economic Perspectives 3, 129-140.

Cnossen, S. (1999), Taxing Capital Income in the Nordic Countries: A Model for the European Union?, Finanzarchiv 56, 18-50.

Fuest, C., B. Huber and S.B. Nielsen (2001), Why is the Corporate Tax Rate Lower than the Personal Tax Rate? The Role of Small Firms, forthcoming in: Journal of Public Economics.

Goldsbee, A. (1998), Taxes, Organizational Form, and the Deadweight Loss of the Corporate Income Tax, Journal of Public Economics 69, 143-152.

Gordon, R. H. (1998), Can High Personal Tax Rates Encourage Entrepreneurial Activity? IMF Staff Papers 45, 49-80.

Gordon, R.H. and J. Slemrod (1998), Are "real" Responses to Taxes Simply Income Shifting between Corporate and Personal Tax Bases? NBER Working Paper No. 6576.

Gordon, R.H. and J.K. MacKie-Mason (1994), Tax Distortions to the Choice of Organizational Form, Journal of Public Economics 55, 279-306.

Gordon, R.H. and J.K. MacKie-Mason (1994), "Why is there Corporate Income Taxation in a Small Open Economy? The Role of Transfer Pricing and Income Shifting," in M. Feldstein and J. Hines (eds.), Issues in International Taxation. Chicago: University of Chicago Press, 67-91.

Kanbur, R. und M. Keen (1993), Jeux sans fontieres: Tax Competition and Tax Coordination when Countries Differ in Size, American Economic Review 83, 877-892.

Harberger, A. (1966), Efficiency Effects of Taxes on Income from Capital, in M. Kryzaniak (ed.) Effects of Corporation Income Tax, Detroit, 107-117.

Haufler, A. and G. Schjelderup (2000), Corporate Tax Systems and Cross Country Profit Shifting, Oxford Economic Papers 52, 306-325.

Kanbur, R. and M. Keen (1993), Jeux sans Fontieres: Tax Competition and Tax Coordination when Countries Differ in Size, American Economic Review 83, 877-892.

Keen, M. (1993). The Welfare Economics of Tax Co-ordination in the European Community: A Survey. Fiscal Studies 14, 15-36.

MacKie-Mason, J.K. and R. H. Gordon (1997), How Much do Taxes Discourage Incorporation?, Journal of Finance 52,477-505.

Messere, K. (1999), Half a Century of Changes in Taxation, Bulletin of International Fiscal Documentation 8-9/1999, 340-365. 
Messere, K. (2000), 20th Century Taxes and their Future, Bulletin for International Fiscal Documentation 1/2000, 2-29.

Mintz, J. (1995), The Corporate Income Tax: A Survey, Fiscal Studies 16, 23-68.

Price Waterhouse (1992), Individual Taxes: A Worldwide Summery.

Weichenrieder, A.J. (1995), Besteuerung und Direktinvestition. Tübingen, Mohr.

Weichenrieder, A.J. (1996a), Fighting International Tax Avoidance: The Case of Germany, Fiscal Studies 17, 37-58.

Weichenrieder, A.J. (1996b), Anti-Tax-Avoidance Provisions and the Size of Foreign Direct Investment, International Tax and Public Finance 3, 67-81.

Wellisch, D. (2000), Theory of Public Finance in a Federal State. Cambridge, Cambridge University Press. 


\section{Appendix}

Table 2: Personal Top Rates on Interest Income (in Percent)

\begin{tabular}{|c|c|c|c|c|c|c|c|c|c|c|c|c|c|}
\hline Year & 1985 & 1986 & 1987 & 1988 & 1989 & 1990 & 1991 & 1992 & 1993 & 1994 & 1995 & 1996 & 1997 \\
\hline Australia & 60 & 57 & 49 & 49 & 48 & 47 & 47 & 47 & 47 & 47 & 47 & 47 & 47 \\
\hline Belgium & 25 & 25 & 25 & 25 & 25 & 10 & 10 & 10 & 10.3 & 13.39 & 13.39 & 15 & 15 \\
\hline Canada (Ontario) & 50.3 & 50.3 & 50.3 & 45 & 43.5 & 43.5 & 46.4 & 46.4 & 46.4 & 52.9 & 49.5 & 48.1 & 48.4 \\
\hline Finland & 71.99 & 71.82 & 71.95 & 72.11 & 64.94 & 64.01 & 61.15 & 63.9 & 25 & 25 & 25 & 28 & 28 \\
\hline France & 26 & 26 & 27 & 27 & 27 & 17 & 18.1 & 18.1 & 18.1 & 19.4 & 19.9 & 20.9 & 25 \\
\hline Germany $^{\mathrm{a}}$ & 56 & 56 & 56 & 56 & 56 & 53 & 54.99 & 54.99 & 53.00 & 53 & 56.98 & 56.98 & 56.98 \\
\hline Italy $^{\mathrm{b}}$ & 25 & 25 & 25 & 25 & 25 & 25 & 25 & 25 & 25 & 25 & 25 & 25 & 25 \\
\hline Japan & 35 & 35 & 35 & 20 & 20 & 20 & 20 & 20 & 20 & 20 & 20 & 20 & 20 \\
\hline Netherlands & 72 & 72 & 72 & 72 & 72 & 60 & 60 & 60 & 60 & 60 & 60 & 60 & 60 \\
\hline Norway & 66.9 & 66.4 & 56 & 48 & 45.6 & 43 & 40.5 & 28 & 28 & 28 & 28 & 28 & 28 \\
\hline Spain & 66 & 66 & 66 & 56 & 56 & 56 & 56 & 53 & 56 & 56 & 56 & 56 & 56 \\
\hline Sweden & 75 & 76.65 & 73.15 & 71.15 & 68.7 & 61.7 & 30 & 30 & 30 & 28 & 28 & 28 & 28 \\
\hline Switzerland (Zurich) & 44.1 & 42.4 & 42.4 & 40.9 & 40.9 & 40.9 & 40.9 & 40.9 & 40.9 & 44 & 45.4 & 42.2 & 42.2 \\
\hline UK & 60 & 60 & 60 & 40 & 40 & 40 & 40 & 40 & 40 & 40 & 40 & 40 & 40 \\
\hline USA (New York) & 58.8 & 58.8 & 50.8 & 36.6 & 36.6 & 36.6 & 36.2 & 36.2 & 36.2 & 46.2 & 47.1 & 47.1 & 46.45 \\
\hline
\end{tabular}

Sources: Institut der deutschen Wirtschaft, Zahlen zur wirtschaftlichen Entwicklung, various issues; Messere (1999/2000); Alworth and Castellucci (1993); Alworth et.al. (2001); Price Waterhouse (1992), several communications with national ministries and international scholars; Office of Tax Policy Research, Michigan, OTPR-data base; several internet sources.

\section{tions:}

${ }^{a}$ Includes solidarity surcharge.

${ }^{\mathrm{b}}$ Typical rate applied to savings accounts. A lower rate is available for government bonds. 
Table 3: Corporate Tax Rates on Retained Earnings (in Percent)

\begin{tabular}{|c|c|c|c|c|c|c|c|c|c|c|c|c|c|}
\hline Year & 1985 & 1986 & 1987 & 1988 & 1989 & 1990 & 1991 & 1992 & 1993 & 1994 & 1995 & 1996 & 1997 \\
\hline Australia & 46 & 49 & 49 & 49 & 39 & 39 & 39 & 39 & 39 & 33 & 36 & 36 & 36 \\
\hline Belgium & 45 & 45 & 43 & 43 & 43 & 41 & 39 & 39 & 40.17 & 40.17 & 40.17 & 40.17 & 40.17 \\
\hline Canada (Ontario) & 50 & 50 & 50 & 38 & 42 & 43.5 & 44.3 & 44.3 & 44.3 & 45.1 & 44.6 & 44.6 & 44.6 \\
\hline Finland & 60.24 & 50.32 & 50.45 & 50.61 & 50.69 & 42.76 & 40.9 & 37.15 & 25 & 25 & 25 & 28 & 28 \\
\hline France & 50 & 45 & 45 & 42 & 39 & 37 & 34 & 34 & 33.33 & 33.33 & 33.33 & 36.7 & 41.7 \\
\hline Germany $^{\mathrm{a}}$ & 62.65 & 62.70 & 62.70 & 62.74 & 62.74 & 57.70 & 59.29 & 59.39 & 57.84 & 53.68 & 56.58 & 56.71 & 56.78 \\
\hline Italy & 46.4 & 46.4 & 46.4 & 46.4 & 46.4 & 46.4 & 47.8 & 47.8 & 47.8 & 52.2 & 52.2 & 52.2 & 37 \\
\hline Japan & 52.3 & 52.3 & 52.3 & 50.7 & 48.3 & 44 & 44 & 44 & 44 & 44 & 44 & 44 & 44.6 \\
\hline Korea & 20 & 30 & 30 & 30 & 30 & 30 & 34 & 34 & 34 & 32 & 30 & 28 & 28 \\
\hline Netherlands & 43 & 42 & 42 & 42 & 35 & 35 & 35 & 35 & 35 & 35 & 35 & 35 & 35 \\
\hline Norway & 39.1 & 39.1 & 39.1 & 39.1 & 39.1 & 39.1 & 39.1 & 28 & 28 & 28 & 28 & 28 & 28 \\
\hline Portugal & 42 & 42 & 42 & 42 & 36 & 36 & 36 & 36 & 36 & 36 & 36 & 36 & 36 \\
\hline Spain & 35 & 35 & 35 & 35 & 35 & 35 & 35 & 35 & 35 & 35 & 35 & 35 & 35 \\
\hline Sweden & 52.4 & 52 & 52 & 52 & 52 & 40 & 30 & 30 & 30 & 30 & 28 & 28 & 28 \\
\hline Switzerland (Zurich) & 34.9 & 33.6 & 33.6 & 30.2 & 30.2 & 30.2 & 34.3 & 34.3 & 34.3 & 34.3 & 35.6 & 35.6 & 35.6 \\
\hline UK & 45 & 35 & 35 & 35 & 35 & 35 & 33 & 33 & 33 & 33 & 33 & 33 & 31 \\
\hline USA (New York) & 58.8 & 58.8 & 51.4 & 39.9 & 45.3 & 45.3 & 45.3 & 45.3 & 45.3 & 45.3 & 45.3 & 48.4 & 46.4 \\
\hline
\end{tabular}

Sources: See Table 2.

\section{Annotations:}

${ }^{a}$ Includes solidarity surcharge and Gewerbesteuer (trade tax) at average local rate (Hebesteuersatz). 


\section{CESifo Working Paper Series}

(for full list see www.cesifo.de)

712 Thorvaldur Gylfason and Gylfi Zoega, Inequality and Economic Growth: Do Natural Resources Matter?, April 2002

713 Wolfgang Leininger, Contests over Public Goods: Evolutionary Stability and the FreeRider Problem, April 2002

714 Ernst Fehr and Armin Falk, Psychological Foundations of Incentives, April 2002

715 Giorgio Brunello, Maria Laura Parisi, and Daniela Sonedda, Labor Taxes and Wages: Evidence from Italy, May 2002

716 Marta Aloi and Huw Dixon, Entry Dynamics, Capacity Utilisation and Productivity in a Dynamic Open Economy, May 2002

717 Paolo M. Panteghini, Asymmetric Taxation under Incremental and Sequential Investment, May 2002

718 Ben J. Heijdra, Christian Keuschnigg, and Wilhelm Kohler, Eastern Enlargement of the EU: Jobs, Investment and Welfare in Present Member Countries, May 2002

719 Tapio Palokangas, The Political Economy of Collective Bargaining, May 2002

720 Gilles Saint-Paul, Some Evolutionary Foundations for Price Level Rigidity, May 2002

721 Giorgio Brunello and Daniela Sonedda, Labor Tax Progressivity, Wage Determination, and the Relative Wage Effect, May 2002

722 Eric van Damme, The Dutch UMTS-Auction, May 2002

723 Paolo M. Panteghini, Endogenous Timing and the Taxation of Discrete Investment Choices, May 2002

724 Achim Wambach, Collusion in Beauty Contests, May 2002

725 Dominique Demougin and Claude Fluet, Preponderance of Evidence, May 2002

726 Gilles Saint-Paul, Growth Effects of Non Proprietary Innovation, May 2002

727 Subir Bose, Gerhard O. Orosel, and Lise Vesterlund, Optimal Pricing and Endogenous Herding, May 2002

728 Erik Leertouwer and Jakob de Haan, How to Use Indicators for 'Corporatism' in Empirical Applications, May 2002

729 Matthias Wrede, Small States, Large Unitary States and Federations, May 2002 
730 Christian Schultz, Transparency and Tacit Collusion in a Differentiated Market, May 2002

731 Volker Grossmann, Income Inequality, Voting Over the Size of Public Consumption, and Growth, May 2002

732 Yu-Fu Chen and Michael Funke, Working Time and Employment under Uncertainty, May 2002

733 Kjell Erik Lommerud, Odd Rune Straume, and Lars Sørgard, Downstream Merger with Oligopolistic Input Suppliers, May 2002

734 Saku Aura, Does the Balance of Power Within a Family Matter? The Case of the Retirement Equity Act, May 2002

735 Sandro Brusco and Fausto Panunzi, Reallocation of Corporate Resources and Managerial Incentives in Internal Capital Markets, May 2002

736 Stefan Napel and Mika Widgrén, Strategic Power Revisited, May 2002

737 Martin W. Cripps, Godfrey Keller, and Sven Rady, Strategic Experimentation: The Case of Poisson Bandits, May 2002

738 Pierre André Chiappori and Bernard Salanié, Testing Contract Theory: A Survey of Some Recent Work, June 2002

739 Robert J. Gary-Bobo and Sophie Larribeau, A Structural Econometric Model of Price Discrimination in the Mortgage Lending Industry, June 2002

740 Laurent Linnemer, When Backward Integration by a Dominant Firm Improves Welfare, June 2002

741 Gebhard Kirchgässner and Friedrich Schneider, On the Political Economy of Environmental Policy, June 2002

742 Christian Keuschnigg and Soren Bo Nielsen, Start-ups, Venture Capitalits, and the Capital Gains Tax, June 2002

743 Robert Fenge, Silke Uebelmesser, and Martin Werding, Second-best Properties of Implicit Social Security Taxes: Theory and Evidence, June 2002

744 Wendell Fleming and Jerome Stein, Stochastic Optimal Control, International Finance and Debt, June 2002

745 Gene M. Grossman, The Distribution of Talent and the Pattern and Consequences of International Trade, June 2002

746 Oleksiy Ivaschenko, Growth and Inequality: Evidence from Transitional Economies, June 2002 
747 Burkhard Heer, Should Unemployment Benefits be Related to Previous Earnings?, July 2002

748 Bas van Aarle, Giovanni Di Bartolomeo, Jacob Engwerda, and Joseph Plasmans, Staying Together or Breaking Apart: Policy-makers' Endogenous Coalitions Formation in the European Economic and Monetary Union, July 2002

749 Hans Gersbach, Democratic Mechanisms: Double Majority Rules and Flexible Agenda Costs, July 2002

750 Bruno S. Frey and Stephan Meier, Pro-Social Behavior, Reciprocity or Both?, July 2002

751 Jonas Agell and Helge Bennmarker, Wage Policy and Endogenous Wage Rigidity: A Representative View From the Inside, July 2002

752 Edward Castronova, On Virtual Economies, July 2002

753 Rebecca M. Blank, U.S. Welfare Reform: What's Relevant for Europe?, July 2002

754 Ruslan Lukach and Joseph Plasmans, Measuring Knowledge Spillovers Using Patent Citations: Evidence from the Belgian Firm's Data, July 2002

755 Aaron Tornell and Frank Westermann, Boom-Bust Cycles in Middle Income Countries: Facts and Explanation, July 2002

756 Jan K. Brueckner, Internalization of Airport Congestion: A Network Analysis, July 2002

757 Lawrence M. Kahn, The Impact of Wage-Setting Institutions on the Incidence of Public Employment in the OECD: 1960-98, July 2002

758 Sijbren Cnossen, Tax Policy in the European Union, August 2002

759 Chandima Mendis, External Shocks and Banking Crises in Developing Countries: Does the Exchange Rate Regime Matter?, August 2002

760 Bruno S. Frey and Lars P. Feld, Deterrence and Morale in Taxation: An Empirical Analysis, August 2002

761 Lars Calmfors and Åsa Johansson, Nominal Wage Flexibility, Wage Indexation and Monetary Union, August 2002

762 Alexander R. W. Robson and Stergios Skaperdas, Costly Enforcement of Property Rights and the Coase Theorem, August 2002

763 Horst Raff, Preferential Trade Agreements and Tax Competition for Foreign Direct Investment, August 2002

764 Alex Cukierman and V. Anton Muscatelli, Do Central Banks have Precautionary Demands for Expansions and for Price Stability? - Theory and Evidence, August 2002

765 Giovanni Peri, Knowledge Flows and Knowledge Externalities, August 2002 
766 Daniel Friedman and Nirvikar Singh, Equilibrium Vengeance, August 2002

767 Sam Bucovetsky and Michael Smart, The Efficiency Consequences of Local Revenue Equalization: Tax Competition and Tax Distortions, August 2002

768 Tapio Palokangas, International Labour Market Regulation and Economic Growth with Creative Destruction, August 2002

769 Rudi Dornbusch, The New International Architecture, September 2002

770 Hans-Werner Sinn, Weber's Law and the Biological Evolution of Risk Preferences: The Selective Dominance of the Logarithmic Utility Function, September 2002

771 Thomas Mayer, The Macroeconomic Loss Function: A Critical Note, September 2002

772 Seppo Honkapohja and Kaushik Mitra, Learning Stability in Economies with Heterogenous Agents, September 2002

773 David Laidler, Inflation Targets Versus International Monetary Integration - A Canadian Perspective, September 2002

774 Morten I. Lau, Panu Poutvaara, and Andreas Wagener, The Dynamic Cost of the Draft, September 2002

775 Steven Brakman, Harry Garretsen, and Charles van Marrewijk, Locational Competition and Agglomeration: The Role of Government Spending, September 2002

776 Anke S. Kessler and Christoph Lülfesmann, The Theory of Human Capital Revisited: On the Interaction of General and Specific Investments, September 2002

777 Kjell Erik Lommerud, Frode Meland and Lars Sørgard, Unionized Oligopoly, Trade Liberalization and Location Choice, September 2002

778 Antonio Merlo and François Ortalo-Magné, Bargaining over Residential Real Estate: Evidence from England, September 2002

$779 \mathrm{Yu}-\mathrm{Fu}$ Chen and Michael Funke, Exchange Rate Uncertainty and Labour Market Adjustment under Fixed and Flexible Exchange Rates, September 2002

780 Michael S. Michael, International Migration, Income Taxes and Transfers: A Welfare Analysis, September 2002

781 Clemens Fuest and Alfons Weichenrieder, Tax Competition and Profit Shifting: On the Relationship between Personal and Corporate Tax Rates, October 2002 